\title{
PENGEMBANGAN PROGRAM, STRATEGI, DAN PERANGKAT PENDUKUNG PEMBINAAN PERILAKU BERLITERASI SISWA SMA BERBASIS KEGIATAN ILMIAH
}

\author{
oleh Suyono \\ FS Universitas Negeri Malang
}

\begin{abstract}
Literacy-activity behavior, the behavior of doing literacy activities (i.e., reading and writing), is very important for students in the completion of their study, their advancement into a higher level of formal education, their preparation for entrance into the world of work, and their life-long education in society. Therefore, such behavior needs to be developed in students at school.

As an effort to develop it in a planned, systematic, and serious way, a program, strategy, and supporting facility for the development of senior high school students' literacy-activity behavior based on scientific activities with an appeal and reliability already tested through developmental research have been developed.

Through empiric try-out and conceptual validation, the program, strategy, and supporting facility have been found to be capable of attracting students' interest and at the same time sufficiently reliable in improving students' awareness, motivation, skill, and fondness of doing literacy activities at school
\end{abstract}

Keywords: literacy, literacy-activity behavior, development of literacy activity behavior

\section{A. PENDAHULUAN}

Beragamnya tantangan yang akan dihadapi siswa dalam kehidupan di masa depan, di satu sisi, dan terbatasnya layanan pembelajaran di sekolah saat ini sebagaimana yang tampak dalam kurikulum dan implementasinya, di sisi lain, semakin mendorong ditemukannya suatu layanan yang secara nyata dapat memenuhi kebutuhan siswa. Layanan itu adalah pembinaan perilaku berliterasi siswa di sekolah. Beberapa bukti penting di bawah ini semakin mendukung perlunya layanan tersebut.

Pertama, temuan penelitian membuktikan bahwa literasi bermanfaat bagi siswa dalam proses dan keberhasilan belajarnya (Strauss dan Irvin, 2003). Adanya literacy hour dan whole-school literacy menjadikan siswa lebih dapat menangkap isi teks, lebih percaya diri dalam berbicara, senang dalam menyelesaikan tugas menulis dan lebih gemar membaca (Cropper, 2001). Kedua, literasi sangat diperlukan oleh masyarakat berbasis pengetahuan yang akan mendominasi abad ke21 (IALS, 2001).

Ketiga, literasi lintas kurikulum dapat meningkatkan penguasaan semua mata pelajaran. Untuk itu guru dituntut mengintegrasikan literasi dalam perencanaan pengajaran sehingga iklim literasi terbangun di sekolah. Melalui cara ini siswa akan mempelajari bahasa dan pengetahuan (isi mata pelajaran) sekaligus (Goodman, 1986; Strong, 2001; Bundy, 2001). Keempat, kemampuan menemukan informasi secara cepat, mengevaluasinya, dan menggunakannya secara efektif untuk berbagai keperluan adalah keterampilan penting yang perlu terus 
ditumbuhkan untuk keberhasilan siswa dan orang dewasa saat ini (Commission on Student Learning/CSL, 1996).

Kelima, literasi merupakan hal yang sangat penting untuk mengembangkan kehidupan. Makin bertambah literasi seseorang, akan semakin tinggi penghasilann dan produktivitas pekerjaannya (ILE, 2001). Bisnis akan sukses bila para tenaga kerjanya memiliki kemampuan literasi dalam bidang yang bervariasi (MLWCC dan MSDE, 2001). Literasi merupakan faktor signifikan untuk mencapai kesuksesan di tempat kerja (Middleton, 2001). Keenam, sekolah mempunyai tanggung jawab atau peranan penting dalam usaha mengembangkan perilaku berliterasi siswa menuju pembelajaran sepanjang hayat (Langford, 2001; IALS, 2001). Dengan demikian, sangat beralasan apabila perilaku berliterasi siswa seharusnya terus dibina dan dikembangkan di sekolah melalui berbagai cara.

Dalam jangka panjang, siswa juga harus dapat mengembangkan kemampuannya untuk menjadi pemikir independen yang mampu memecahkan masalah-masalah nyata dalam kehidupannya dengan mengikuti caracara pemecahan mutakhir (CSL, 1996). Untuk menghadapi dan mencapai keberhasilan dalam berbagai tantangan tersebut, siswa dituntut memiliki bekal dasar yang memadai. Bekal dasar yang dimaksud adalah kemampuan berliterasi. Kemampuan berliterasi adalah kemampuan sinergis yang intinya adalah perpaduan kemampuan membaca-berpikirmenulis (Eanes, 1997; SCANS, 2001). Kemampuan sinergis tersebut dapat dimiliki siswa bila mereka memperoleh pengalaman aktivitas berliterasi secara terus-menerus baik di dalam maupun di luar kelas (Langford, 2001; Cropper, 2001). Oleh karena itu, perlu dicarikan layanan pembelajaran yang tepat untuk dapat meningkatkan kesadaran, motivasi, keterampilan, dan kegemaran berliterasi siswa serta melestarikan keempat aspek tersebut dalam kehidupan sehari-hari di sekolah.

Selanjutnya, pembinaan perilaku berliterasi siswa di sekolah dapat terlaksana dengan baik apabila mempunyai basis yang jelas dan kuat. Keberadaan basis di sini diposisikan sebagai kondisi yang dapat mempermudah dan mendorong pembinaan perilaku berliterasi. Dalam Adolescent Literacy in the Content Area/ALCA (2003), basis itu disebut sebagai research-based strategies. Dijadikannya kegiatan ilmiah sebagai basis pembinaan perilaku berliterasi siswa diharapkan dapat mengondisikan siswa mengembangkan kesadaran, motivasi, keterampilan, dan kegemaran berliterasinya karena adanya tuntutan untuk melakukan beragam kegiatan ilmiah, termasuk berlatih meneliti.

Di sisi lain, dipilihnya kegiatan ilmiah sebagai basis pembinaan perilaku berliterasi juga didasari oleh beberapa pertimbangan, yakni (1) kegiatan ilmiah merupakan kegiatan penting dalam pembentukan keterampilan berpikir ilmiah yang akan dibutuhkan siswa dalam kehidupan, (2) melalui kegiatan ilmiah siswa akan belajar menemukan ilmu pengetahuan dan teknologi, walaupun dalam taraf yang sederhana, dan (3) kegiatan ilmiah, termasuk penelitian, merupakan kegiatan ekstrakurikuler yang perlu ditonjolkan di sekolah.

Dipilihnya jenjang SMA sebagai konteks penelitian ini didasari oleh pertimbangan bahwa kesadaran, motivasi, keterampilan, dan kegemaran berliterasi siswa (1) sangat diperlukan oleh lulusan SMA yang akan melanjutkan studi (13,75\%) (Mastuhu, 2004), (2) diperlukan pula oleh sebagian besar $(86,25 \%)$ lulusan SMA yang memasuki dunia kerja (walaupun sebenarnya tidak dirancang secara khusus untuk langsung bekerja), dan (3) sangat diperlukan oleh lulusan SMA yang tidak atau belum melanjutkan studi dan belum bekerja, terutama untuk belajar mandiri sepanjang hayat di tengah masyarakat.

Bertolak dari konteks di atas, penelitian pengembangan ini bertujuan: (1) menghasilkan produk untuk pembinaan perilaku berliterasi siswa SMA berbasis kegiatan ilmiah yang berupa program, strategi, dan perangkat pendukungnya, dan (2) menjelaskan 
kemenarikan dan keandalan program, strategi, dan perangkat pendukung pembinaan perilaku berliterasi siswa SMA berbasis kegiatan ilmiah serta mengetahui kondisi-kondisi yang diperlukan untuk mengoptimalkan pembinaan perilaku berliterasi siswa dengan menggunakan produk penelitian ini.

\section{B. METODE PENGEMBANGAN}

Untuk mencapai tujuan pengembangan di atas digunakan tiga tahapan prosedural, yakni tahap prapengembangan, pengembangan, dan tahap uji coba produk (McKenney, 2001; Universitas Negeri Malang, 2003). Dari ketiga tahapan tersebut telah dihasilkan program, strategi, dan perangkat pendukung pembinaan perilaku berliterasi yang teruji di lapangan. Mengingat pelibatan siswa sebagai subjek penelitian dan temuannya melalui uji coba penggunaan produk (hasil pengembangan) bersifat terbatas, penelitian pengembangan ini bersifat studi kasus, yakni tidak dimaksudkan untuk mencapai generalisasi (Yin, 1996).

Pelaksanaan ketiga tahapan pengembangan ini melibatkan siswa, guru, dan pakar. Siswa dan guru di sekolah yang dijadikan tempat penggalian informasi awal dan kegiatan uji coba produk masing-masing diperlakukan sebagai subjek utama dan subjek pendukung uji coba hasil pengembangan, sedangkan pakar diposisikan sebagai validator hasil pengembangan. Untuk melaksanakan ketiga tahapan penelitian tersebut digunakan sejumlah instrumen, yakni (a) panduan pengamatan dan pencatatan lapangan, (b) panduan analisis isi, (c) angket (untuk siswa dan guru), (d) panduan wawancara (untuk siswa dan guru), (e) pedoman pengembangan, dan (f) format balikan pakar. Dengan demikian, sesuai dengan tujuan pengembangan dan instrumen yang digunakan, teknik pengumpulan data dilakukan dengan menggunakan teknik pengamatan dan pencatatan lapangan, analisis isi, angket, dan wawancara.

Tahap prapengembangan telah menghasilkan dasar-dasar pengembangan dan spesifikasi produk. Selanjutnya, tahap pengembangan telah menghasilkan program, strategi, dan perangkat pendukung pembinaan perilaku berliterasi siswa SMA berbasis kegiatan ilmiah (produk awal). Terakhir, tahap uji coba penggunaan produk berisi kegiatan menggunakan program, strategi, dan perangkat pendukung pembinaan perilaku berliterasi siswa berbasis kegiatan ilmiah di sekolah. Melalui tahap uji coba inilah produk pengembangan ini terus disempurnakan.

Tahap uji coba empirik dan validasi konseptual dilakukan melalui uji coba penggunaan produk di lapangan. Uji coba itu dilakukan dalam dua tahap, yakni uji coba terbatas (uji coba terbatas I, II, III, dan IV) dan uji coba diperluas. Peneliti sebagai human instrument mengumpulkan data uji coba dengan menggunakan metode pengamatan dan pencatatan lapangan, angket, dan wawancara dengan siswa dan guru. Untuk validasi konseptual, dilibatkan pakar teknologi pembelajaran dan bidang studi bahasa Indonesia.

Selanjutnya, data dalam tahap prapengembangan dan uji coba produk yang berupa data kualitatif dianalisis secara kualitatif, sedangkan data kuantitatif dianalisis dengan menggunakan teknik analisis kuantitatif. Teknik analisis kualitatif menggunakan metode analisis kritis, kreatif, reflektif, dan prediktif. Dalam proses analisis kualitatif tersebut digunakan matrik analisis dengan mengembangkan tema-tema analisis sesuai dengan tujuan pengembangan. Sementara itu, analisis data kuantitatif hanya sampai tahap persentase untuk menggambarkan kecenderungan perkembangan jumlah peserta dalam pembinaan perilaku literasu dan jumlah karyanya serta kategori-kategori kualitas karya yang dihasilkan. Hasil analisis secara kualitatif dan kuantitatif selanjutnya dimanfaatkan untuk: (1) merumuskan dasar-dasar pengembangan dan spesifikasi produk (acuan pengembangan produk), (2) menyempurnakan produk, (3) menjelaskan kondisi-kondisi yang dapat mengoptimalkan penggunaan produk, dan (4) menjelaskan kemenarikan dan 
keandalan produk untuk pembinaan perilaku berliterasi siswa SMA di sekolah.

\section{HASIL PENGEMBANGAN DAN UJI COBA PRODUK}

Wujud akhir produk yang dikembangkan melalui penelitian pengembangan ini adalah program dan strategi pembinaan perilaku berliterasi siswa yang terintegrasi ke dalam enam perangkat pendukung, yakni (1) Panduan Umum Pembinaan Perilaku Berliterasi Siswa SMA, (2) Panduan Khusus 1: Dari Meneliti Menuju Literasi, (3) Panduan Khusus 2: Pembinaan Perilaku Berliterasi Siswa SMA Berbasis Kegiatan Ilmiah (Panduan Khusus 2), (4) Panduan Ringkas Pembinaan Perilaku Berliterasi Siswa SMA Berbasis Kegiatan Ilmiah Melalui Pengalaman Belajar Lintas Kurikulum dan Layanan Jam Literasi, (5) Lembar-lembar Pendorong Pembinaan Perilaku Berliterasi Siswa SMA Berbasis Kegiatan Ilmiah, dan (6) Panduan Guru dalam Pembinaan Perilaku Berliterasi Siswa SMA Berbasis Kegiatan Ilmiah.

Dalam enam perangkat di atas, secara garis besar terdapat program, strategi, dan implementasinya di lapangan. Program pembinaan perilaku berliterasi terdiri atas empat program, yakni (i) program peningkatan kesadaran dan motivasi berliterasi siswa, (ii) program peningkatan keterampilan berliterasi siswa, (iii) program peningkatan kegemaran berliterasi siswa, dan (iv) program pelestarian kesadaran, motivasi, keterampilan, dan kegemaran berliterasi siswa di sekolah. Selanjutnya, strategi pembinaan perilaku berliterasi terdiri atas strategi lintas kurikulum dan strategi layanan jam literasi. Kedua strategi tersebut saling berhubungan, dengan penegasan strategi kedua merupakan kelanjutan dan penajaman strategi pertama. Terakhir, implementasi pembinaan perilaku berliterasi siswa di sekolah dipandu dalam setiap panduan, baik dalam Panduan Umum, Panduan Khusus 1, Panduan Khusus 2, Panduan Ringkas, Lembar-lembar Pendorong, maupun Panduan Guru. Implementasi pembinaan perilaku berliterasi menempatkan siswa pada posisi sentral, sementara itu guru dan peneliti sebagai fasilitatornya. Sebagai fasilitator, guru dan peneliti memberikan bimbingan, menjawab pertanyaan, dan membantu mereka yang mengalami kesulitan.

Penyempurnaan produk secara bertahap meliputi penambahan program, strategi, dan perangkat pendukung pembinaan perilaku berliterasi siswa berbasis kegiatan ilmiah. Penyempurnaan produk dilakukan secara bertahap dan berkesinambungan sepanjang kegiatan uji coba. Sementara itu, kondisi-kondisi yang dapat mengoptimalkan penggunaan produk mencakup: (1) kesabaran guru untuk terus-menerus memotivasi siswa, (2) iklim pembelajaran yang menantang siswa, (3) pertemuan rutin siswa dengan peneliti atau guru untuk membahas berbagai hal di luar jam pelajaran (melalui layanan jam literasi), (4) kelompok-kelompok diskusi di kelas yang dibentuk atas prakarsa siswa dan dukungan peneliti dan guru, (5) tantangan untuk membuat majalah dinding atau bendel tematik, (6) adanya teman sebaya untuk mendorong siswa yang lain berliterasi, (7) adanya kumpulan atau bendel hasil-hasil penelitian, dan (8) tawaran atau kesempatan untuk mengikuti berbagai perlombaan yang berkaitan dengan membaca, berpikir, meneliti dan menulis.

Mengenai kemenarikan produk dijelaskan bahwa produk yang berupa program, strategi, dan perangkat pendukung pembinaan perilaku berliterasi siswa berbasis kegiatan ilmiah ternyata dapat menarik perhatian dan sekaligus mendorong siswa SMA mengembangkan perilaku berliterasinya di sekolah. Secara kuantitatif kemenarikan produk juga dapat dilihat dari perkembangan jumlah peserta yang terlibat, jumlah bacaan yang dibaca dan jumlah karya tulis yang dihasilkan siswa. Demikian juga mengenai keandalannya, produk ini dapat menumbuhkan dan meningkatkan kesadaran, motivasi, keterampilan, dan kegemaran berliterasi serta dapat melestarikan perilaku berliterasi siswa SMA tersebut di sekolah. Secara kuantitatif, keandalan produk dapat dilihat dari perkembangan jumlah bacaan yang dibaca, jumlah karya dan mutu karya tulis 
yang dihasilkan siswa di sekolah yang terus meningkat.

\section{PEMBAHASAN}

\section{Hasil Pengembangan dan Teori Literasi}

Setidaknya ada tujuh landasan teoretik yang dapat menguatkan hasil pengembangan penelitian ini. Tujuh landasan teoretik itu adalah, pertama, literasi merupakan aspek yang sangat bernilai untuk kehidupan modern yang berbasis pengetahuan (Bluestein, 1994; DEETYA, 1998; ABC Canada, 2001; SSHCR Canada, 2001; IALS, 2001, dan Maryland Literacy Works Compaign Committee, 2001). Kedua, literasi sangat diperlukan siswa untuk menjadi pemikir independen yang mampu memecahkan berbagai masalah dan tantangan nyata dalam kehidupannya (CSL, 1996; Eanes, 1997, SCANS, 2001), karenanya siswa perlu memperoleh pengalaman berliterasi secara terus-menerus baik di dalam maupun di luar kelas (Langford, 2001; Cropper, 2001).

Ketiga, temuan penelitian membuktikan bahwa literasi bermanfaat bagi siswa dalam proses belajarnya (Cropper, 2001). Keempat, literasi lintas kurikulum dapat meningkatkan penguasaan isi mata pelajaran (Goodman, 1986; Strong, 2001, dan Bundy, 2001). Kelima, sekolah mempunyai tanggung jawab dan peranan penting dalam usaha mengembangkan literasi siswa menuju pembelajaran sepanjang hayat (Langford, 2001).

Keenam, literasi merupakan hal yang sangat penting untuk mengembangkan kehidupan, misalnya dalam kaitannya dengan produktivitas pekerjaan (ILE, 2001; MLWCC dan MSDE, 2001; Middleton, 2001. Ketujuh, ada empat kondisi yang perlu diperhatikan dalam pembinaan perilaku berliterasi, yakni eksplisit, sistematis, bersungguh-sungguh, dan kontekstual (Cambaourne, 1999). Paparan teoretik tersebut menunjukkan bahwa program, strategi, dan perangkat pendukung pembinaan perilaku berliterasi siswa SMA berbasis kegiatan ilmiah hasil penelitian ini memang sangat diperlukan bagi siswa dan guru di sekolah.

\section{Hasil Pengembangan dan Tantangan Kehidupan Modern bagi Siswa}

Pemanfaatan program, strategi, dan perangkat pendukung serta kondisi-kondisi pembinaan perilaku berliterasi untuk menyiapkan siswa memasuki kehidupan modern berbasis pengetahuan (Bluestein, 1994; DEETYA, 1998; ABC Canada, 2001; SSHRC Canada, 2001; IALS, 2001, dan Maryland Literacy Works Compaign Committee, 2001). Suka atau tidak suka, siap atau tidak siap kecenderungan ke arah pemanfaatan pengetahuan sebagai basis kehidupan modern tidak terelakkan lagi. Itu artinya, siswa sebagai calon pemilik kehidupan masa depan perlu disadarkan dan sekaligus diberi kondisi yang memungkinkan mereka dapat belajar memanfaatkan pengetahuan untuk meningkatkan kualitas kehidupannya. Hal itu sejalan dengan salah satu pandangan Joni (1989) bahwa pendidikan harus benar-benar membentuk sumber daya manusia yang mempunyai kemampuan dan kemauan berpikir di dalam menganalisis dan memahami permasalahan masa depan secara ilmiah.

Mengingat pengetahuan sebagai basis kehidupan modern, siswa harus disiapkan ke arah itu. Pembinaan perilaku berliterasi di sekolah merupakan langkah yang tepat. Upaya tersebut sesuai dengan salah satu pandangan Bundy (2001) bahwa perilaku berliterasi memungkinkan terjadinya produksi pengetahuan baru yang diperlukan bagi kemajuan (ekonomi) bangsa untuk waktu yang akan datang. Bagaimana implementasinya? Sejak awal siswa diajak untuk belajar memanfaatkan pengetahuan dalam memahami dan memecahkan berbagai persoalan kehidupan di sekitarnya atau menemukan peluang-peluang.

Kecenderungan kuat bahwa pengetahuan merupakan basis kehidupan modern juga menuntut manusia mampu mengakses, mengolah, dan menggunakan pengetahuan yang diperloleh dari teks tertulis sebagaimana yang dinyatakan Goodman (1986). Pembinaan perilaku berliterasi siswa di sekolah sangat mendukung terwujudnya 
keterampilan tersebut. Dengan demikian, pembinaan perilaku berliterasi dengan menggunakan program, strategi, dan perangkat pendukung sebagaimana yang dihasilkan penelitian pengembangan ini sangat tepat untuk itu.

Membaca dan menulis bila digabungkan dengan mendengar, melihat, berbicara, dan berpikir kritis merupakan aspek yang sangat bernilai untuk kehidupan modern. Literasi memungkinkan seseorang berinteraksi dengan berbagai sumber informasi yang kompleks (Blustein, 1994; DEETYA, 1998). Manfaat literasi tersebut apabila dicermati akan sangat menguntungkan siapa pun, termasuk siswa, untuk memasuki kehidupan modern. Mereka akan bisa berkiprah dan mengambil bagian untuk terlibat aktif dalam kehidupan modern tersebut apabila memiliki perilaku berliterasi yang tinggi. Hanya dengan pembinaan yang jelas perilaku berliterasi tersebut dapat terwujud.

Salah satu jenjang literasi adalah jenjang literasi tingkat tinggi. Dalam jenjang literasi itu tercakup kemampuan memanipulasi atau memainkan berbagai simbol, teori-teori, informasi dan lain-lain sebagaimana kerja ilmuwan. Orientasi pembinaan perilaku berliterasi siswa akan diarahkan menuju ke jenjang literasi tingkat tinggi ini (Langshear, 2001). Apalagi dengan dijadikannya penelitian sebagai basis pembinaan perilaku berliterasi orientasi itu akan relatif mudah dicapai. Dengan demikian, program, strategi, dan perangkat pendukung pembinaan perilaku berliterasi siswa hasil penelitian pengembangan ini akan mendukung upaya menyiapkan siswa memasuki kehidupan modern berbasis pengetahuan.

\section{Hasil Pengembangan dan Tantangan Siswa untuk Memecahkan Masalah}

Pemanfaatan program, strategi, dan perangkat pendukung, serta kondisi-kondisi pembinaan perilaku berliterasi untuk mengondisikan siswa menjadi pemikir independen yang mampu memecahkan berbagai masalah dan tantangan nyata dalam kehidupannya. Dalam tatanan ekonomi global, menurut Fiske, kompetisi bukan didasarkan pada ukuran besar-kecilnya bangsa, lokasi, atau ketersediaan sumberdaya alam, akan tetapi lebih didasarkan pada kapasitas warga negara untuk berpikir, belajar, berkreasi, dan memecahkan masalah (dalam Eanes, 1997). Keempat kapasitas warga negara tersebut memang sangat dibutuhkan dalam persaingan global saat ini dan terlebih-lebih untuk waktu yang akan datang.

Lebih lanjut, untuk memecahkan berbagai masalah dan tantangan nyata dalam kehidupan diperlukan informasi yang relevan dan cukup. Dalam kaitan itu, siswa perlu mengembangkan kemampuan membaca dan menggunakan informasi tertulis (Langford, 1998; Middleton, 2001). Kemampuan itu akan dapat dimiliki siswa apabila mereka memperoleh pengalaman belajar yang memadai. Itu berarti, siswa hendaknya diarahkan dan dikondisikan untuk mengembangkan berbagai kapasitas tersebut dengan baik. Untuk itu, diperlukan adanya wadah yang memadai. Dalam hal ini, program, strategi, dan perangkat pendukung pembinaan perilaku berliterasi siswa SMA berbasis kegiatan ilmiah dapat dimanfaatkan di sekolah untuk membantu mengembangkan kapasitas siswa sebagaimana disebutkan di atas.

Informasi yang telah berhasil dikumpulkan hakikatnya merupakan bahan yang masih perlu diolah. Untuk keperluan itu, siswa dituntut memiliki kemampuan berpikir yang memadai. Agar siswa dapat mengaktualisasikan potensi berpikirnya secara optimal perlu fasilitas yang tepat. Adanya program, strategi, dan perangkat pendukung pembinaan perilaku berliterasi hasil penelitian pengembangan ini dapat mengondisikan pengembangan potensi berpikir siswa. Dengan memanfaatkan informasi yang telah berhasil dikumpulkan melalui kegiatan membaca, siswa akan dapat meneruskan kegiatan berpikirnya melalui menulis. Pengalaman belajar yang demikian itu sejalan dengan pandangan Gillet (1994) dan Eanes (1997) bahwa membacaberpikir-menulis merupakan alat untuk belajar 
atau reading, writing, and critical thinking as a tools for learning.

\section{Hasil Pengembangan dan Tuntutan Siswa untuk Memperoleh Pengalaman Berliterasi}

Pemanfaatan program, strategi, dan perangkat pendukung, serta kondisi-kondisi pembinaan perilaku berliterasi untuk mengondisikan siswa memperoleh pengalaman berliterasi di dalam dan di luar kelas. Agar hasilnya lebih optimal, pengalaman berliterasi perlu dikondisikan dan ditumbuhkan baik di dalam maupun di luar kelas. Pendekatan sosiokultural memandang bahwa literasi bukan sekedar membaca-menulis yang bersifat mekanik, tetapi merupakan praktik sosial atau proses sosial sebagaimana dikemukakan $\mathrm{Au}$ (1995). Sebagai proses sosial, literasi juga dapat digunakan sebagai alat untuk mencapai tujuan ekstrinsik (Street, 1984 dan Smith, 1985). Pandangan lain menyatakan bahwa mambacamenulis sebagai inti literasi diperlukan untuk menyelesaikan sebagian besar tugas yang harus diselesaikan siswa (DeStefano, 1984). Membaca-menulis juga akan memberdayakan siswa untuk mengadakan eksplorasi dan meneliti menuju pembelajar yang independen (Eanes, 1997).

Untuk mewujudkan pandanganpandangan di atas perlu diciptakan program, strategi, dan perangkat pendukung yang memungkinkan pembinaan perilaku berliterasi terjadi di dalam dan di luar kelas. Adanya program, strategi, dan perangkat pendukung pembinaan perilaku berliterasi hasil penelitian ini memungkinkan hal tersebut terlaksana dengan baik. Selain itu, adanya program, strategi, dan perangkat pendukung juga akan membimbing siswa dapat memanfaatkan waktu yang dimiliki lebih terarah. Adanya tantangan untuk membaca, berfikir, meneliti, dan menulis sebagai wujud pelaksanaan program pembinaan perilaku berliterasi akan mengondisikan siswa memperoleh pengalaman berliterasi baik di dalam maupun di luar kelas secara optimal.

\section{Hasil Pengembangan dan Kegiatan Berliterasi Lintas Kurikulum}

Pemanfaatan program, strategi, dan perangkat pendukung serta kondisi-kondisi pembinaan perilaku berliterasi dapat mengondisikan siswa memperoleh pengalaman berliterasi lintas kurikulum. Kelas-kelas mata pelajaran merupakan latar yang ideal untuk praktik pengembangan keterampilan berliterasi (Eanes, 1997). Keberhasilan program pembinaan perilaku berliterasi untuk semua level mensyaratkan program tersebut diintegrasikan dalam kegiatan lintas kurikulum. Melalui cara ini siswa akan mempelajari bahasa dan pengetahuan (bahan ajar) sekaligus (Goodman, 1986; TEISCC, 2001; Strong, 2001). Selanjutnya, pembinaan perilaku berliterasi lintas kurikulum secara sengaja dapat terlaksana dengan baik apabila didasari oleh program, strategi, dan perangkat pendukung yang jelas. Produk penelitian pengembangan ini mendukung upaya tersebut. Landasan perlunya pembinaan perilaku berliterasi lintas kurikulum ini dapat dirujuk dalam Kurikulum Berbasis Kompetensi, terutama pada bagian kompetensi lintas kurikulum (Depdiknas, 2003).

Pembinaan perilaku berliterasi lintas kurikulum tidak hanya bermanfaat bagi upaya penumbuhan dan peningkatan kesadaran, motivasi, keterampilan, dan kegemaran berliterasi itu sendiri, akan tetapi juga membantu siswa memahami dan mendalami materi beragam mata pelajaran secara lintas bidang sebagaimana dinyatakan oleh Strong (2001) dan Giroux (2001) sehingga pemahaman siswa lebih komprehensif dan tidak hanya sektoral seperti yang sering terjadi di sekolah saat ini. Dalam kaitan itu memang tidak setiap materi pelajaran dapat dan harus dipelajari secara lintas kurikulum. Artinya, hanya materi yang memang layak dipelajari secara lintas kurikulum yang perlu diperlakukan seperti itu. Tegasnya, tidak perlu dipaksakan bahwa setiap materi pelajaran harus dipelajari secara lintas kurikulum.

Lebih tegas lagi, bahwa pembinaan perilaku berliterasi lintas kurikulum menurut 
McKenna dan Robinson dapat memaksimalkan pemerolehan isi pelajaran (dalam Eanes, 1997). Beach (1984) juga menyatakan bahwa membaca-menulis penting bagi siswa untuk mendalami bahan ajar dan mengembangkan keterampilan berpikir. Itu berarti, adanya program, strategi, dan perangkat pendukung pembinaan perilaku berliterasi yang dilaksanakan dengan strategi lintas kurikulum sebagaimana yang dilakukan dalam penelitian ini bermanfaat bagi siswa untuk menyelesaikan studinya.

Pengalaman berliterasi lintas kurikulum juga dapat memadukan kemampuan berbahasa, berpikir, dan penguasaan substansi materi pelajaran secara terpadu (Langer, 2000). Dengan menggunakan program, strategi, dan perangkat pendukung pembinaan perilaku berliterasi hasil penelitian ini pengalaman berliterasi lintas kurikulum dapat terwujud di sekolah yang pelaksanaannya dapat dilakukan secara leluasa oleh siswa dengan guru sebagai pendampingnya. Melalui cara ini siswa tidak merasa tertekan, tetapi sebaliknya dapat belajar berliterasi sesuai dengan irama belajarnya masing-masing.

Belajar lintas kurikulum melalui kegiatan berliterasi atau bisa juga berliterasi secara lintas kurikulum akan mendorong terjadinya proses berpikir kritis (Tierney, 1989). Konkretnya, praktik menulis esai yang diawali dengan membaca beragam sumber kemudian berpikir kritis dan menulis akan memberi kesempatan kepada siswa menghubung-hubungkan dan berpikir lebih luas tentang topik atau masalah yang ditulis sehingga siswa lebih fleksibel dalam mengembangkan ide-ide kreatifnya sebagaimana dinyatakan Langer dan Applebee (1987). Dengan demikian, pembinaan perilaku berliterasi lintas kurikulum merupakan upaya realistis yang perlu diujicobakan (Resnick, 1988; CED, 2001).

\section{Hasil Pengembangan dan Penyiapan Siswa untuk Memasuki Dunia Kerja}

Pemanfaatan program, strategi, dan perangkat pendukung serta kondisi-kondisi pembinaan perilaku berliterasi untuk mempersiapkan siswa memasuki dunia pekerjaan. Dunia pekerjaan pasti akan dimasuki siswa suatu saat nanti. Lulusan SMA yang tidak melanjutkan pendidikannya ke jenjang yang lebih tinggi jumlahnya lebih banyak (lebih dari $80 \%$ ) bila dibandingkan dengan yang meneruskan ke perguruan tinggi (kurang dari $20 \%$ ). Baik yang tidak melanjutkan maupun yang melanjutkan ke pendidikan yang lebih tinggi pada akhirnya semuanya akan memasuki dunia pekerjaan. Apa yang perlu dipersiapkan untuk mereka? Salah satu yang sangat penting adalah kesadaran, motivasi, keterampilan dan kegemaran berliterasi yang tinggi.

Makin bertambah kesadaran, motivasi, keterampilan, dan kegemaran berliterasi seseorang, akan semakin tinggi penghasilan dan produktivitas kerjanya (ILE, 2001). Bisnis akan semakin sukses bila para tenaga kerjanya memiliki kemampuan berliterasi dalam bidang yang bervariasi (MLWCC dan MSDE, 2001). Literasi merupakan faktor yang signifikan untuk mencapai kesuksesan di tempat kerja (Middeton, 2001). Pandangan lain menyatakan bahwa literasi bermanfaat untuk memenuhi kebutuhan di tempat kerja sehingga dapat mempertinggi kualitas hidup di masyarakat (Green, 2001; Seaforss, 1994). Lebih lengkap lagi pandangan Gee (1996) yang menyatakan bahwa kemampuan atau perilaku berliterasi baik secara individual maupun berkelompok merupakan wahana untuk memperoleh keuntungan dalam pekerjaan, ilmu pengetahuan, pengembangan diri, pertumbuhan ekonomi, inovasi dan sebagainya.

Penjelasan di atas membuktikan bahwa literasi memang mempunyai peranan yang penting bagi siapa saja yang akan memasuki dunia pekerjaan dan sekaligus meningkatkan kinerjanya di bidangnya masing-masing. Itu berarti tidak beralasan apabila di sekolah siswa tidak mendapat layanan pembinaan perilaku berliterasi yang memadai. Oleh karena itu, kehadiran program, strategi, dan perangkat pendukung pembinaan perilaku berliterasi hasil penelitian pengembangan ini sangat diperlukan. Apalagi telah terbukti bahwa 
penggunaan produk penelitian pengembangan ini dapat meningkatkan kesadaran, motivasi, keterampilan, dan kegemaran berliterasi siswa di sekolah. Pengalaman itu diharapkan dapat dibawa siswa ketika mereka memasuki dunia pekerjaan di tengah masyarakat.

\section{Hasil Pengembangan dan Tanggung Jawab Sekolah}

Pemanfaatan program, strategi, dan perangkat pendukung serta kondisi-kondisi pembinaan perilaku berliterasi memungkinkan sekolah melaksanakan tanggung jawab dan peranannya dalam usaha mengembangkan perilaku berliterasi siswa menuju pembelajaran sepanjang hayat. Hal itu sesuai dengan The Centre for Literacy (2001) yang menyatakan bahwa literasi merupakan bagian dari pembelajaran sepanjang hayat manusia dewasa. Dengan demikian, belajar sepanjang hayat merupakan suatu keniscayaan bagi setiap individu di tengah masyarakat. Adanya kemauan dan langkah nyata untuk belajar sepanjang hayat memungkinkan setiap individu mengikuti setiap kemajuan, mempunyai wawasan yang luas, memiliki kehidupan yang berkualitas, mampu berkarya nyata, dan mempunyai perilaku produktif dalam hidupnya. Keadaan yang demikian itu pasti dicita-citakan dan ingin dicapai oleh setiap orang. Sekolah mempunyai tanggung jawab dan peranan yang penting dalam usaha mengembangkan perilaku berliterasi siswa menuju pembelajaran sepanjang hayat tersebut (Langford, 2001).

Literasi bermanfaat bagi seseorang baik di rumah, di tempat kerja maupun di masyarakat. Literasi sekaligus juga merupakan kemampuan yang dibutuhkan untuk belajar sepanjang hayat terutama dalam masyarakat berbasis pengetahuan (MLWCC, 2001; ABC Canada, 2001; SSHRC, 2001). Manfaat literasi yang besar tersebut perlu mendapat perhatian dalam praktik pendidikan di sekolah. Artinya, perlu pembinaan perilaku berliterasi secara sungguh-sungguh. Untuk itu adanya program, strategi, dan perangkat pendukung pembinaan perilaku berliterasi hasil penelitian ini akan sangat berguna.

Sekolah mempunyai tanggung jawab yang besar untuk mengembangkan perilaku berliterasi siswa. Oleh karena itu, para guru dituntut dapat memanfaatkan peran strategisnya dalam pembinaan perilaku berliterasi siswa di sekolah. Hasil penelitian menunjukkan bahwa guru yang mendorong siswanya membaca-menulis melalui tugastugas terstruktur dapat membantu siswa mengintegrasikan pengetahuan yang diperoleh dari setiap mata pelajaran dengan pengetahuan yang telah dimilikinya (pengetahuan pribadinya) (Jeffries-Thaiss dan Th. Thaiss, 2001). Dengan demikian, tantangan kegiatan berliterasi sebagaimana yang diujicobakan melalui penelitian ini-sebagaimana yang tampak dalam program, strategi, dan perangkat pendukungnya - dapat mendukung atau sejalan dengan hasil penelitian di atas.

\section{Hasil Pengembangan dan Pelaksanaan Pembinaan Perilaku Berliterasi Siswa di Sekolah}

Pemanfaatan program, strategi, dan perangkat pendukung pembinaan perilaku berliterasi memungkinkan terjadinya pelaksanaan pembinaan perilaku berliterasi siswa secara eksplisit, sistematis, bersungguhsungguh, dan kontekstual. Berdasarkan penelitiannya, Cambaourne (1999) menyimpulkan bahwa pembinaan perilaku berliterasi yang memenuhi empat kondisi di atas lebih berhasil. Penggunaan program, strategi, dan perangkat pendukung pembinaan perilaku berliterasi hasil penelitian pengembangan ini memungkinkan terjadinya empat kondisi tersebut. Artinya, dengan produk penelitian pengembangan ini, pembinaan perilaku berliterasi siswa dilaksanakan secara eksplisit (sengaja). Selain itu, pembinaan perilaku berliterasi dilaksanakan secara sistematis, yakni direncanakan sebelumnya dalam suatu program.

Pentingnya perencanaan dan usaha sistematis dalam pembinaan perilaku berliterasi juga dinyatakan oleh Cropper (2001) bahwa perilaku berliterasi siswa meningkat ketika 
dilakukan usaha sistematis dengan menerapkan aktivitas berliterasi di sekolah. Penggunaan produk penelitian pengembangan ini juga memungkinkan pembinaan perilaku berliterasi siswa dilaksanakan secara sungguh-sungguh. Adanya kebebasan bagi siswa untuk mencari dan menemukan masalah, isu, atau topik yang dibaca, dipikirkan, diteliti, dan ditulis memungkinkan mereka (siswa) belajar berliterasi secara kontekstual. Oleh karena itu, kehadiran program, strategi, dan perangkat pendukung hasil penelitian pengembangan ini akan mengondisikan pembinaan perilaku berliterasi siswa di sekolah lebih berhasil.

Perihal kemanfaatan produk penelitian ini dalam upaya menciptakan kondisi pembinaan perilaku berliterasi yang eksplisit, sistematis, bersungguh-sungguh, dan kontekstual juga dikuatkan oleh pandangan Salinger (2001) yang menyatakan bahwa lingkungan mahir baca-tulis (literate environment) ternyata dapat meningkatkan pembelajaran karena mereka (siswa) menggunakan proses-proses yang saling berkaitan antara membaca, menulis, berbicara, dan mendengarkan untuk komunikasi alamiah senyatanya. Lingkungan yang kaya bahan cetakan dan memberi kesempatan untuk menggunakannya akan mendorong siswa mengujicobakan dengan literasi. Lingkungan seperti inilah yang ditawarkan oleh program, strategi, dan perangkat pendukung pembinaan perilaku berliterasi hasil penelitian pengembangan ini.

\section{Kemenarikan dan Keandalam Hasil Pengembangan}

Kemenarikan dan keandalan program, strategi, dan perangkat pendukung, serta kondisi-kondisi pembinaan perilaku berliterasi untuk meningkatkan kesadaran, motivasi, keterampilan, dan kegemaran berliterasi siswa sesuai dengan pembelajaran kontekstual. Program, strategi, dan perangkat pendukung serta kondisi-kondisi pembinaan perilaku berliterasi dapat menarik perhatian siswa karena keempat hal tersebut bermanfaat, realistis, dan mudah digunakan.
Kebermanfaatan program, strategi, dan perangkat pendukung serta kondisi-kondisi pembinaan perilaku berliterasi setidaknya dapat dilihat dari daya dorong dan kemampuan memfasilitasi keempat hal tersebut untuk meningkatkan kesadaran, motivasi, keterampilan, dan kegemaran berliterasi serta pelestarian keempat aspek tersebut pada diri siswa.

Keempat aspek perilaku berliterasi siswa tumbuh dan meningkat pada saat program, strategi, dan perangkat pendukung pembinaan perilaku berliterasi digunakan. Adanya keterlibatan peneliti (dalam layanan jam literasi) dan guru (secara lintas kurikulum) yang secara bersama-sama mendorong siswa berliterasi juga dapat mendukung perilaku berliterasi siswa. Hal ini sesuai dengan temuan Sturtevant (2004) bahwa guru perlu diarahkan dan didorong secara terus-menerus mengembangkan perilaku berliterasi siswa di sekolah melalui kegiatan pembelajarannya. Untuk itu, produk penelitian pengembangan ini perlu disosialisasikan kepada guru di lapangan dan selanjutnya mereka diharapkan dapat mengujicobakannya di sekolah masingmasing.

Sementara itu, kerealistisan program, strategi, dan perangkat pendukung serta kondisi-kondisi pembinaan perilaku berliterasi dapat dijelaskan dari konteks keseharian di sekolah. Tuntutan agar siswa banyak membaca, berpikir, meneliti, dan menulis sangat realistis bagi siswa, mengingat itu semua sesungguhnya dunia mereka yang sedang belajar dan menuntut ilmu. Kalau pun selama ini kurang tampak itu hanya karena tuntutan, iklim, dan keadaan di sekolah yang kurang mendukung bagi terwujudnya tradisi tersebut. Kecenderungan ke depan-dengan pemberlakuan Kurikulum Baru-programprogram yang ditawarkan dalam produk penelitian pengembangan ini sesuai dengan kebutuhan di sekolah.

Selanjutnya, kemudahan penggunaan program, strategi, dan perangkat pendukung serta kondisi-kondisi pembinaan perilaku berliterasi siswa berbasis kegiatan ilmiah 
setidaknya dapat dijelaskan dengan dua hal, pertama, adanya kebebasan atau keleluasaan siswa dalam memilih topik atau isu yang akan dibaca, dipikirkan, diteliti, dan ditulis. Topik atau isu yang dipilih dianjurkan yang paling menarik minat mereka dan sekaligus ada di sekitar tempat tinggalnya atau bisa juga yang berhubungan dengan materi yang sedang dipelajarinya. Kedua, waktu yang digunakan untuk membaca, berpikir, meneliti, dan menulis tidak dibatasi atau harus menggunakan waktu tertentu. Siswa diberi keleluasaan untuk memilih dan menggunakan waktu yang dimilikinya sesuai dengan seleranya, baik di sekolah maupun di luar sekolah.

Khusus mengenai kegiatan ilmiah yang dijadikan basis dalam pembinaan perilaku berliterasi telah memberikan pengalaman tersendiri bagi siswa. Ketertarikan siswa terhadap program, strategi, dan perangkat pendukung pembinaan perilaku berliterasi juga tak lepas dari penggunaan basis kegiatan ilmiah. Bahan-bahan bacaan yang disediakan sebagian berupa laporan-laporan penelitian yang dihasilkan oleh siswa SMP dan SMA dari berbagai daerah sebagaimana yang telah dimuat dalam harian Republika. Ketertarikan siswa terhadap produk penelitian ini khususnya yang berkaitan dengan basis kegiatan ilmiah dapat dijelaskan dengan temuan The Knowledge Loom (2003) bahwa untuk mendukung literasi remaja perlu empat komponen, yakni motivasi, strategi berbasis kegiatan ilmiah, pembinaan lintas kurikulum, dan dukungan kelembagaan. Kegiatan ilmiah ternyata merupakan salah satu kunci menuju keberhasilan pembinaan perilaku berliterasi siswa.

Sementara itu, mengenai keberadaan motivasi dalam pembinaan perilaku berliterasi, yang juga dijadikan salah satu program dalam produk penelitian ini (program peningkatan kesadaran dan motivasi), menurut Cooper (2000) merupakan satu dari tiga komponen penting dalam program pembinaan literasi siswa. Dua komponen yang lain adalah pengajaran membaca dan menulis dan aktivitas membaca dan menulis secara independen.
Untuk menumbuhkan dan memelihara motivasi siswa, dalam penelitian pengembangan ini (1) telah digunakan bahan-bahan bacaan yang dapat membangkitkan motivasi, (2) siswa ditantang untuk menghasilkan bendel-bendel tematik karya siswa, dan (3) siswa diajak, dibimbing, dan terlibat secara langsung dalam layanan jam literasi. Pengalaman-pengalaman dan fasilitas itulah yang telah berperan dalam membangkitkan dan memelihara motivasi siswa sebagai salah satu komponen penting untuk keberhasilan pembinaan perilaku berliterasi mereka di sekolah.

Basis kegiatan ilmiah yang mengondisikan siswa banyak membaca, berpikir, mencari dan menemukan masalah, melakukan penelitian sederhana, dan menulis tampaknya juga merupakan daya tarik tersendiri bagi siswa. Mereka merasa ada nuansa baru yang selama ini kurang mendapat perhatian secara sungguh-sungguh. Oleh karena itu, kemenarikan basis kegiatan ilmiah juga mudah dipahami mengingat selama ini kegiatan belajar hanya berkutat pada membaca buku teks, menghafal, dan mengemukakan kembali apabila diperlukan ketika ada pertanyaan dari guru atau menghadapi ulangan/ujian. Dengan adanya basis kegiatan ilmiah siswa merasa ada variasi dalam belajar.

Lebih lanjut, mengenai kemenarikan dan keandalan kegiatan ilmiah sebagai basis pembinaan perilaku berliterasi juga dapat dijelaskan berdasarkan prinsip-prinsip konstruktivisme pembelajaran literasi yang dikemukakan $\mathrm{Au}$ (1995). Prinsip-prinsip itu diantaranya adalah menggunakan aktivitas otentik, mendorong siswa membangun pemahaman sendiri, dan mendorong siswa untuk saling berinteraksi. Penggunaan strategi lintas kurikulum dan layanan jam literasi di sekolah sebagaimana yang digunakan dalam penelitian pengembangan ini dapat memudahkan perwujudan prinsip-prinsip tersebut.

\section{E. PENUTUP}

Kegiatan pengembangan telah menghasilkan tiga produk, yakni (1) empat 
program pembinaan perilaku berliterasi siswa SMA berbasis kegiatan ilmiah, (2) dua strategi pembinaan perilaku berliterasi siswa SMA berbasis kegiatan ilmiah, dan (3) enam perangkat pendukung pembinaan perilaku berliterasi siswa SMA berbasis kegiatan ilmiah. Simpulan dari proses dan hasil pengembangan program, strategi, dan perangkat pendukung pembinaan perilaku berliterasi siswa SMA berbasis kegiatan ilmiah dan hasil uji cobanya di sekolah sebagai berikut.

Pertama, simpulan mengenai proses dan hasil pengembangan. Program, strategi, dan perangkat pendukung pembinaan perilaku berliterasi siswa SMA berbasis kegiatan ilmiah - hasil pengembangan ini-ketiganya merupakan suatu keutuhan. Ketiga produk itu dihasilkan berdasarkan hasil analisis kebutuhan, aspek-aspek perilaku berliterasi, dan dihasilkan secara bertahap melalui proses pengembangan dan uji coba sesuai dengan kebutuhan di sekolah. Program pembinaan perilaku berliterasi siswa dapat dilaksanakan dengan baik apabila didukung oleh strategi yang tepat. Program dan strategi yang tepat dapat diaktualisasikan di sekolah dengan baik apabila didukung oleh perangkat pendukung yang memadai, baik untuk siswa maupun guru.

Kedua, simpulan mengenai hasil uji coba produk. Secara umum, uji coba produk menghasilkan temuan bahwa produk yang dihasilkan melalui penelitian pengembangan ini menarik bagi siswa dan cukup andal untuk meningkatkan kesadaran dan motivasi berliterasi, meningkatkan keterampilan berliterasi, meningkatkan kegemaran berliterasi serta melestarikan kesadaran, motivasi, keterampilan, dan kegemaran berliterasi siswa di sekolah. Kemenarikan dan keandalan program, strategi, dan perangkat pendukung pembinaan perilaku berliterasi siswa SMA berbasis kegiatan ilmiah itu utamanya ditandai oleh respon siswa dan kemajuan perilaku mereka dalam berliterasi setelah menggunakan produk penelitian pengembangan ini. Hal itu menunjukkan bahwa produk penelitian pengembangan ini layak dipertimbangkan untuk digunakan di lapangan secara luas dengan memperhatikan aspekaspek kondisional.

Selanjutnya, terkait dengan hasil uji coba produk ini, dapat dirumuskan simpulansimpulan: (1) perilaku berliterasi siswa dapat ditingkatkan dengan menggunakan program, strategi, dan perangkat pendukung yang memadai, (2) untuk menggunakan program, strategi, dan perangkat pembinaan perilaku berliterasi siswa perlu adanya kondisi yang mendukung, (3) untuk melaksanakan pembinaan perilaku berliterasi siswa perlu kehadiran strategi yang berkelanjutan, yakni terintegrasi dalam pembelajaran (intrakurikuler) dan diteruskan dengan kegiatan di luar pembelajaraan (ekstrakurikuler), dan (4) penggunaan perangkat pendukung pembinaan perilaku berliterasi siswa dapat memudahkan guru dan siswa dalam meningkatkan perilaku berliterasi siswa di sekolah.

Selanjutnya, berdasarkan kajian terhadap produk dapat disimpulkan bahwa program, strategi, dan perangkat pendukung pembinaan perilaku berliterasi siswa berbasis kegiatan ilmiah ini dapat: (1) menyiapkan siswa memasuki kehidupan modern berbasis pengetahuan, (2) menyiapkan siswa menjadi pemikir independen yang mampu memecahkan berbagai masalah, (3) mengondisikan siswa memperoleh pengalaman literasi di dalam dan di luar kelas, (4) mengondisikan siswa berliterasi secara lintas kurikulum, (5) mengondisikan siswa mempersiapkan diri memasuki dunia pekerjaan dan belajar sepanjang hayat, dan (6) mengondisikan siswa berliterasi secara eksplisit, sistematis, bersungguh-sungguh dan kontekstual. Oleh karena itu, produk penelitian pengembangan ini layak dipertimbangkan untuk didesiminasikan dan digunakan di sekolah-sekolah.

Kepada siswa, guru, kepala sekolah, dan kepada dinas pendidikan kabupaten/kota dan provinsi disarankan hal-hal berikut. Pertama, saran untuk siswa. Berdasarkan hasil penelitian pengembangan ini, siswa SMA yang terlibat dalam penelitian ini disarankan (1) terus memanfaatkan program, strategi, dan perangkat pendukung pembinaan perilaku 
berliterasi siswa SMA hasil penelitian ini, (2) terus meningkatkan kesadaran, motivasi, keterampilan, dan kegemaran berliterasi di sekolah, (3) bekerjasama dengan guru untuk terus memikirkan dan memberi masukan agar program, strategi, dan perangkat pendukung pembinaan perilaku berliterasi siswa SMA menjadi lebih baik, dan (4) mendokumentasikan secara cermat dan sistematis dalam "buku harian pembinaan perilaku berliterasi" semua pengalaman dan temuan yang didapat melalui berbagai kegiatan pembinaan perilaku berliterasi siswa di sekolah. Sementara itu, siswa SMA lainnya (siswa SMA yang tidak digunakan untuk uji coba) dianjurkan untuk mengujicobakan (mencoba menggunakan) program, strategi dan perangkat pendukung pembinaan perilaku berliterasi siswa hasil penelitian ini di sekolah masing-masing.

Kedua, saran untuk guru. Kepada guru SMA yang terlibat dalam penelitian ini disarankan hal-hal berikut (1) guru SMA (sangat) dianjurkan untuk terus mengujicobakan atau menggunakan program, strategi, dan perangkat pendukung pembinaan perilaku berliterasi siswa hasil penelitian pengembangan ini di sekolah, (2) terus mendorong siswa dalam menumbuhkan kesadaran, motivasi, keterampilan, dan kegemaran berliterasi siswa di sekolah melalui berbagai cara, (3) bekerjasama dengan siswa untuk terus memikirkan program, strategi, dan perangkat pendukung pembinaan perilaku berliterasi siswa SMA yang lebih baik, dan (4) mendokumentasikan secara cermat dan sistematis dalam "buku harian pembinaan perilaku berliterasi" semua pengalaman dan temuan yang didapat melalui berbagai kegiatan pembinaan perilaku berliterasi siswa di sekolah. Sementara itu, guru SMA lainnya dianjurkan untuk mengujicobakan program, strategi dan perangkat pendukung pembinaan perilaku berliterasi siswa hasil penelitian pengembangan ini di sekolah masing-masing.

Ketiga, saran untuk kepala sekolah. Kepada kepala sekolah yang terlibat dalam penelitian ini disarankan untuk mendukung usaha guru dan siswa dalam menumbuhkan kesadaran, motivasi, keterampilan, dan kegemaran berliterasi siswa dengan menggunakan program, strategi dan perangkat pembinaan perilaku berliterasi hasil penelitian ini serta menyediakan fasilitas yang dibutuhkan. Kepada kepala SMA lainnya disarankan untuk mengujicobakan strategi dan perangkat pendukung pembinaan perilaku berliterasi siswa SMA hasil penelitian pengembangan ini di sekolah masing-masing, mencatat pengalaman dan temuannya, dan memberi masukan kepada peneliti demi penyempurnaan hasil penelitian pengembangan ini.

Keempat, saran untuk kepala dinas pendidikan kabupaten/kota dan provinsi. Kepala dinas pendidikan kabupaten/kota dan provinsi disarankan mempelajari dan selanjutnya dapat menganjurkan kepada sekolah-sekolah di wilayah kerjanya untuk mengujicobakan program, strategi, dan perangkat pendukung pembinaan perilaku berliterasi siswa SMA hasil penelitian pengembangan ini.

Kelima, untuk peneliti lain disarankan melakukan penelitian sejenis dengan cara (1) mengembangkan program, strategi, dan perangkat pendukung pembinaan perilaku berliterasi yang lain untuk SMA, (2) mengujicobakan produk penelitian ini dengan sasaran yang lebih banyak, dan (3) melakukan penelitian lanjutan dengan program, strategi, dan perangkat yang berbeda dengan sasaran yang berbeda, tetapi masih dalam lingkup pembinaan perilaku berliterasi siswa di sekolah.

\section{DAFTAR PUSTAKA}

ABC Canada. 2001. The Impact of Basic Skills Programs on Canadian Workplaces, (online), (http://www.abc-canada.org/)

Adolescent Literacy in The Content Area (ALCA). 2003. Four Key Componens of the Adolescent Literacy Support Framewor. (http://www. knowledgeloom.org/media/bprinter.ht ml.) 
Au, Kathryn H; Jana M. Mason; dan Judith A. Scheu. 1995. Literacy Instruction for Today. New York: HarperCollins

Beach, Richard dan Lillian Bridwell. 1984. Learning Through Writing: A Rationale for Writing Across the Curriculum. The Development of Oral and Written Language in School Contexts.

Pellegrini, Anthony D. dan Thomas D. Yawkey (eds.). Norwood: Ablex Publishing Co.

Bluestein, Christine. 1994. I Can Read! Empowering Young Readers for Success. Natural Approaches to Reading and Writing. Patricia Antonacci dan Carolyn Hedley (eds.). Norwood: Ablex Publishing Co.

Bundy, Alan. 2001. Information Literacy: The Key Competency for the 21" Century. (http://www.library.unisa.edu.au/pape rs/inlit21.htm)

Cambourne, Brian. 1999. Conditions for Literacy Learning. The Reading Teacher. Vol. 53. No. 2. October 1999.

Commission on Student Learning (CSL). 1996. "Introduction: The Basics, Plus" Essesntial Academic Learning Requirements: Science, Social Studies, Art, Health and Fitness-Technical Manual. http://www.wlma. org/literacy/eslintro.html)

Council on Economic Development (CED). 2001. "High Literacy" and Language Art Curriculum. School Improvement in Maryland. (http://www.mdk12.org/ practices/good_instruction/ projectbetter/elangarts/ela-64-66.html

Cooper, J.D. 2000. Literacy: Helping Children Construct Meaning. Boston: Houghton Mifflin Company

Cropper, E. 2001. Secondary Literacy Success (online). Literacy Issues and Database. (http://www.literacytrust.org.uk/Datab ase/myrtle.html)

DEETYA/Departement of Employment, Education, and Training and Youth Affairs Australia.. 1998. Literacy for All: The Challenge for Australia
School. Canberra: JS McMillan Printing Group

Depdiknas. 2003. Kurikulum Berbasis Kompetensi: Ketentuan Pokok,Pengembangan Silabus, dan Pengelolaan KBK. Jakarta: Depdiknas

DeStefano, Johanna S. 1984. Learning to Communicate in the Classroom. The Development of Oral and Written Language in Social Contexts. Pellegrini, Anthony D. dan Thomas D. Yawkey (eds.). Norwood: Ablex Publishing Co.

Eanes, Robin. 1997. Content Area Literacy: Teaching for Today and Tomorrow. Albany: Delmar Publisher

Gee, J.P. 1996. Social Linguistics and Literacies: Ideology and Discourses. ${ }^{2}$ edn. London: Taylor \& Francis

Gillet, J. Wallace dan Charles Temple. 1994. Understanding Reading Problems: Assessment and Instruction. Fourth E d i t i o n. N e w Y o r k : HarperCollinsCollegePublishers

Giroux, Henry. 2001. Thingking Skills: Writing. School Improvement in Maryland. (online). (http://www. mdk12.org/practices/good_instruction /projectbetter/social/ss-63-64.html)

Goodman, Keneth S. 1986. Literacy: for Whom and What. Language in Learning. Selected Papers from the RELC Seminar on "Language Accross the Curriculum" Singapore, 22-26 April 1985

Green, D.A. 2001. Literacy, Numeracy, and Labour Market Outcomes inCanada. (online), (http://www.nald.ca/NLS/ ials/numeracy/hilight/hilights1.htm), diakses 21/8/2001.

International Adult Literacy Survey (IALS). 2001. An Introduction. (online). http://www.nald.ca/nls/ials/ crintro.html)

International Literacy Explorer/ILE. 2001. Literacy and Development. (online). (http://www.literacy.org/explorer/over 
view.html) (17/8/2001)

Jeffries-Thaiss dan Ch. Thaiss. 2001. Writing as a Learning Tool. School Improvement i n M a ryland. (on line). (http://www.mdk12.org/practices/goo d.Instruction/projectbetter/elangarts/el a-7-9.html) (diakses 29/10/01)

Joni, T. Raka 1989. "Mereka Masa Depan, Sekarang: Tantangan bagi Pendidikan dalam Menyongsong Abad Informasi”, disajikan dalam Ceramah Ilmiah Dies Natalis XXXV IKIP MALANG, 18 Oktober 1989

Langer, J.A. dan Applebee, A.N.1987. How Writing Shapes Thinking: A Study of Teaching and Learning. Urbana IL.: National Council of Teachers of English

Langer, Judith dan Sheila Flihan. 2000. Writing and Reading Relationship: Constructive Task. (online) (http:www. knowledgeloom.org/resources.jsp?loc ation $=6 \&$ tool/

Lankshear, Colin. 2001. Literacy Studies in Education: Disciplined Developments in a Post-Disciplinary Age. (online), (http://www.geocities.com)

Langford, Linda. 1998. Information Literacy: A Clarification. (http://www.ennfyes. iserver.net/ oct98/clarity.html)

Langford, Linda. 2001. Information Literacy: A Clarification. (http://www.emifyes. iserver.net/fromnow/oct98/clarify. html)

Maryland Literacy Works Campaign Committee and the Maryland State Departement of Education (MLWCC \& MSDE). 2001. Literacy Works. (http://www.research.umbc.edu/ ira/ litwksfact.html) (diakses 17/8/2001)

Mastuhu. 2004. Menata Ulang Pemikiran Sistem Pendidikan Nasional dalam Abad 21. Yogyakarta: Sifiria Insania Press bekerja sama dengan Magister Studi Islam UII

McKenney, S. 2001. Computer-based Support for Science Education Materials
Developers in Africa: Exploring Potensials. Disertasi Doktor. Twente: University of Twenty

Middleton, Sandy. 2001. "It Guided Me Back to Learning." (online) (http://www. nad.ca/Province /Bc/Lbc/Research/ pg5.htm) (16/8/2001)

Resnick, L. 1988. Education and Learning to Think. Washington, D.C.: National Academy Press Salinger, Terry. 2001. Literate Environment. School Improvement in Maryland. (http:www. mdk12.org/practices/good_instructio/ projectbetter/)

Searfoos, Lyndon W. dan John E. Readence.1994. Helping Children Learn to Read. Boston: Allyn and Bacon

Secretary's Commission on Achieving Necessary Skills (SCANS). 2001. Skills and Competencies Needed to Successed in Today's Workplace. (http://www.ncrel.org/ sdrs/areas/ issues/methods/assesment/as 7 scans. html)

Smith, David M. 1983. Reading and Writing in the Real World: Explorations into the Culture of Literacy. Developing Literacy. Robert P. Parker dan Frances A. Davis (eds.). Newark: International Reading Association

Social Sciences and Humanities Research Council of Canada/SSHRC Canada. 2001. Literacy: Overview. (online), (http://www.sshrc.ca/archive/literacy. html.)

Strauss, Susan E. and Irvin, Judith L. 2003. Exemplary Literacy Learning Programs: What Research Says. (online) (http://www.nmsa.org/ services/exemplary.html) (diakses 5/8/2004)

Street, B. 1984. Literacy in Theory and Practice. Cambridge: Cambridge University Press.

Strong, Julia. 2001. Making Literacy Across the Curriculum Effective. (http://www. 
literacytrust.org.uk/Pubs/juliasec.htm) Sturtevant, Elizabeth G. 2004. The Literacy Coach. Alliance for Excellent Education. (http://www.all4ed.org, diakses 20/8/2004)

TEISCC. 2001. Essential Skills for Information Literacy. (http://www.wlma.org/ literacy)

The Centre for Literacy. 2001. The Politics of Literacy Policy. (http:// www.nald.ca/ PROVINCI/QUE/litcent/NEWSLETT /Vol15no2/htm)

The Knowledge Loom. 2003. Four Key Component of the Adolescent Literacy
Support Framework. (http://www. knowledgeloom.org/media/html).

Tierney, R.J., dkk. 1989. The effects of reading and writing upon thinking Critically. Reading Research Quarterly, 24 (1), $568-580$

Universitas Negeri Malang (UM). 2003. Pedoman Penulisan Karya Ilmiah. Edisi Keempat. Malang: Universitas Negeri Malang

Yin, Robert K. 1996. Studi Kasus: Desain dan Metode. Penerjemah M. Djauzi Mudzakir. Jakarta: RajaGrafindo Persada 